\title{
Chemical composition and antioxidant activity of geopropolis produced by Melipona fasciculata (Meliponinae) in flooded fields and cerrado areas of Maranhão State, northeastern Brazil
}

\author{
Marisa Cristina Aranha BATISTA ${ }^{1}$; Bruno Vinicius de Barros ABREU ${ }^{1}$; Richard Pereira DUTRA ${ }^{1}$; \\ Mayara Soares CUNHA ${ }^{1}$; Flavia Maria Mendonça do AMARAL ${ }^{1}$; Luce Maria Brandão TORRES²; \\ Maria Nilce de Sousa RIBEIRO ${ }^{*}$

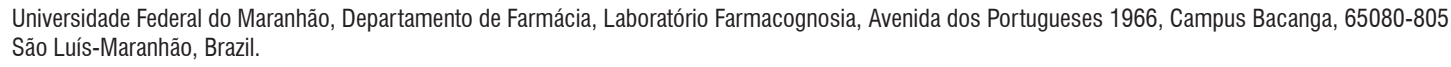

\begin{abstract}
Geopropolis, a mixture of plant resin, wax, soil and salivary secretion, is produced by the stingless bee Melipona fasciculata. This aim of this study was to investigate the chemical composition and antioxidant activity of geopropolis collected from beehives in two phytogeographical regions, flooded fields and cerrado, in the municipalities of Palmeirândia and Fernando Falcáo, Maranhão State, northeastern Brazil. The geopropolis compounds were identified by gas chromatography-mass spectrometry (GC/MS). Additionally, total phenolic content was determined with the Folin-Ciocalteu reagent and antioxidant activity was evaluated in vitro by 2,2-diphenyl-1-picrylhydrazyl (DPPH) and ferric reducing antioxidant power (FRAP) assays. The four geopropolis samples varied in terms of total phenolic content and antioxidant activity and the highest values were observed for geopropolis from Fernando Falcão. Triterpenes such as cycloartane, ursane and oleanane and phenolic acids (protocatechuic acid and gallic acid) were identified in the geopropolis from Palmeirândia, while the phenolic acids, gallic and ellagic acid were the main compounds in geopropolis from Fernando Falcão. The antioxidant property of geopropolis is due to its high total phenolic content and predominance of gallic acid and ellagic acid. The results showed that the plant resources in two phytogeographical regions of Maranhão used by bees for the production of geopropolis contribute to the chemical composition and bioactivity of this product.
\end{abstract}

KEYWORDS: stingless bee, polyphenols, triterpenes, phytogeographical regions.

\section{Composição química e atividade antioxidante da geoprópolis de Melipona fasciculata (Meliponinae) produzida em áreas de campos alagados e de cerrado no Estado do Maranhão, Nordeste do Brasil}

\section{RESUMO}

Geoprópolis, uma mistura de resinas vegetais, cera, terra e secreção salivar, produzida pela abelha sem ferrão Melipona fasciculata. Este estudo investigou a composição química e a atividade antioxidante da geoprópolis coletada em colmeias em duas regiôes fitogeográficas de campos alagados e de cerrado, nos municípios de Palmeirândia e Fernando Falcáo, no Estado do Maranhão, Nordeste do Brasil. Os compostos da geoprópolis foram identificados por cromatografia gasosa acoplada a espectrometria de massas (CG/EM). Foram determinados os teores de fenólicos totais pelo reagente de Folin-Ciocalteu, e atividade antioxidante utilizando o ensaio in vitro com 2,2-difenil-1-picrilhidrazil (DPPH) e capacidade redutora do ferro (FRAP). As quatro amostras de geoprópolis apresentaram variaçóes no teor de fenólicos totais e atividade antioxidante, as geoprópolis de Fernando Falcăo, apresentaram maiores teores. Nas geoprópolis do município de Palmeirândia foram identificados, triterpenos do tipo cicloartano, ursano e oleanano e ácidos fenólicos (ácido protocatecuico e ácido gálico), enquanto que na geoprópolis de Fernando Falcão, ácidos fenólicos, ácido gálico e elágico foram os principais constituintes. A propriedade antioxidante da geoprópolis pode ser atribuída aos altos teores de fenólicos totais e de ácido gálico e elágico. Os resultados demonstram que as fontes vegetais das duas regióes fitogeográficas do Maranhão, Brasil, utilizadas pelas abelhas para a produção da geoprópolis contribuem para a composição química e bioatividade deste produto.

PALAVRAS-CHAVE: abelhas sem ferrão, polifenóis, triterpenos, regiōes fitogeográficas. 


\section{INTRODUCTION}

Stingless bees are found in Tropical and Neotropical regions and play an important role in pollination and agriculture (Slaa et al. 2006). In Brazil, 244 stingless bee species have been identified mainly in the northern and northeastern regions of Brazil, corresponding to about $20 \%$ of all Neotropical species of stingless bees (Pedro 2014).

In the State of Maranhão (northeastern Brazil), Melipona fasciculata Smith, popularly known as tiuba, is the species most frequently cultivated for honey production by rural populations, especially in flooded fields and cerrado areas, because of its high economic value and the production of wax, pollen, and geopropolis. The last product has potential applications in the fields of chemistry and biology, but few studies have been conducted (Bezerra 2002; Bankova and Popova 2007; Holanda et al. 2012).

In the beehives, geopropolis is produced by bees from the resinous material of buds, leaves, and plant exudates, mixed with salivary secretions, wax, and soil. Geopropolis is used to protect beehives against insects and pathogenic microorganisms, to restrict entry into the hive, to line the interior walls of the hive, to strengthen the honeycombs, and embalm animals (Nogueira-Neto 1997).

Geopropolis and its subproducts are used by the population for the treatment of inflammatory diseases, fatigue, hemorrhoids, gastritis, and cough (Kerr 1987). Several studies have demonstrated the biological properties of geopropolis, such as antimicrobial, cytotoxic, antitumor, antioxidant, antinociceptive, antiinflammatory, immunomodulatory, and gastroprotective (Libério et al. 2011; Souza et al. 2014; Araújo et al. 2015).

The chemical composition of geopropolis is complex. It has been reported the presence of polyphenolic compounds (phenolic acids, flavonoids, and tannins) (Silva et al. 2013; Souza et al. 2013; Dutra et al. 2014), terpenes (monoterpenes, sesquiterpenes, diterpenes, and triterpenes), fatty acids, steroids, and saponins (Dutra et al. 2008; Cunha et al. 2009; Araújo et al. 2015). However, its chemical composition varies according to the flora visited by stingless bees, the region, and the time of collection (Bankova 2009; Ribeiro et al. 2013; Barth and Freitas 2015).

In view of the scarcity of studies on the chemical composition and biological activity of $M$. fasciculata products in Brazil, the aim of this study was to investigate the chemical composition of geopropolis produced by $M$. fasciculata collected from beehives of two phytogeographical regions of Maranhăo, and evaluate its antioxidant activity.

\section{MATERIALS AND METHODS}

\section{Geopropolis samples}

Four geopropolis samples: G1 (660.5 g), G2 (496.4 g), G3 (1519.0 g) and G4 (2534.8 g) were collected from meliponaries located in two phytogeographical regions of Maranháo State, northeastern Brazil. Samples G1 and G2 were collected in two beehives of the same meliponary in the

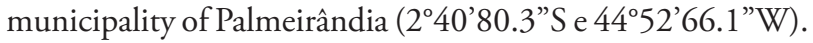
Palmeirândia is located in the region of periodically flooded fields (lowlands of the northern micro-region of Maranhão, northeastern Brazil) with the predominance of "castanha do Pará" (Bertholletia excelsa Humb. \& Bonpl.), "embaúba" (Cecropia sp.), "gameleira" (Clusia burchellii Engl.), "cedro" (Cedrella fissilis Vell.) and "babaçu” (Orbignya phalerata Mart.). During the rainy season, the lowlands are flooded, forming islands of dry land with occurrence of "buriti" (Mauritia flexuosa L.f.), "aninga" (Montrichardia linifera Schott), among others (Martins et al. 2011).

Samples G3 and G4 were collected from two beehives of the same meliponary in the municipality of Fernando

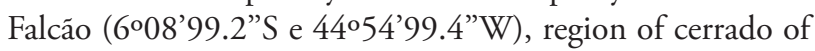
the southern micro-region of Maranháo, northeastern Brazil. This region is characterized by typical cerrado vegetation with species of great ecological and economic value, such as "barbatimão" (Stryphnodendron barbatiman M.), "gonçalave" (Astronium graveolens Jacq.), "mangabeira” (Hancornia speciosa Muell. Arg.), "piqui" (Caryocar brasiliensis Camb.), "fava d'anta" (Dimorphandra gardneriana L.), "candeia" (Platymenia reticulata Benth.), "tamboril" (Enterolobium contortisiliquum (Vell.) Morong), "puça" (Mouriri pusa Gardn.), "sucupira" (Bowdichia virgilioides HBK.), "murici" (Byrsonima crassifolia HBK.), "cagaita" (Eugenia dysenterica DC.) and "pau terra" (Qualea grandiflora Mart.) (Muniz 2002; Ribeiro et al. 2013).

\section{Preparation of hydroalcoholic extracts of geopropolis (HEG)}

The geopropolis samples $(500 \mathrm{~g})$ were separately macerated with $1: 2(\mathrm{w} / \mathrm{v})$ in $70 \%$ ethanol for $48 \mathrm{~h}$ and filtered to separate the inorganic part (soil). The extractive solutions were concentrated in a rotating evaporator (Q344B2, Quimis, São Paulo, Brazil) to yield HEG (Dutra et al. 2014). The extracts were codified as HEG1 and HEG2 (geopropolis collected from Palmeirândia), and as HEG3 and HEG4 (geopropolis collected from Fernando Falcáo).

\section{Total phenolic content (TPC)}

Total phenolic compounds were determined by the FolinCiocalteu reagent and 20\% sodium carbonate method (Dutra et al. 2014). The reaction mixture was kept in the dark for $2 \mathrm{~h}$ at room temperature, and absorbance was measured at $760 \mathrm{~nm}$ using a UV-Vis spectrophotometer (Lambda 35, 
Perkin Elmer Corporation, Massachusetts, USA). TPC was expressed as milligrams of gallic acid equivalent per gram of geopropolis extracts ( $\mathrm{mg} \mathrm{GAE} \mathrm{g}^{-1}$ ).

\section{Determination of the antioxidant activity}

\section{DPPH radical scavenging activity}

The antioxidant activity of geopropolis samples was evaluated using the in vitro 2,2-diphenyl-1-picrylhydrazyl (DPPH) assay (Dutra et al. 2014). The samples were diluted in methanol at different concentrations (1.0 to $100.0 \mu \mathrm{g}$ $\left.\mathrm{mL}^{-1}\right)$ and added to a methanol solution of DPPH (40.0 $\left.\mu \mathrm{g} \mathrm{mL}{ }^{-1}\right)$. After $30 \mathrm{~min}$ of reaction at room temperature in the dark, the absorbance of each solution was read at $517 \mathrm{~nm}$ using a UV-Vis spectrophotometer (Lambda 35, Perkin Elmer Corporation, Massachusetts, USA). Methanol was used as the control and DPPH solution was used as the blank. Standards of gallic acid and 6-Hydroxy-2,5,7,8tetramethylchromane-2-carboxylic acid (Trolox, Sigma) were treated under the same conditions as the samples. The percent inhibition was calculated according to equation.

$\mathrm{DPPH}$ $(\%)=100 \mathrm{x}\left(A_{\text {control }}-A_{\text {sample }}\right) / A_{\text {control }}$

where $A_{\text {sample }}=$ absorbance of the sample after $30 \mathrm{~min}$ of reaction, and $A_{\text {control }}=$ absorbance of the control. The percent of scavenging activity was plotted against the sample concentration to obtain the $\mathrm{IC}_{50}$, defined as the concentration of sample necessary to cause $50 \%$ inhibition.

\section{Ferric reducing antioxidant power assay (FRAP)}

The FRAP's method was used to determine the antioxidant activity based on iron reduction. FRAP measures the ferric-reducing ability of a sample in acid medium ( $\mathrm{pH} 3.6$ ), yielding an intense blue color attributable to the reduction of the ferric tripyridyltriazine ( $\mathrm{Fe}^{\mathrm{III}}-\mathrm{TPTZ}$ ) complex to the ferrous ( $\mathrm{Fe}^{\mathrm{II}}$ ) form (Dutra et al. 2014). FRAP reagent was prepared immediately before analysis by mixing $25 \mathrm{~mL}$ of acetate buffer $(300$ $\mathrm{mM}, \mathrm{pH}$ 3.6), $2.5 \mathrm{~mL}$ of TPTZ solution (10 mM TPTZ in $40 \mathrm{mM} \mathrm{HCl})$, and $2.5 \mathrm{~mL}$ of $\mathrm{FeCl}_{3} \cdot 6 \mathrm{H}_{2} \mathrm{O}(20 \mathrm{mM})$ in aqueous solution. Different concentrations of $100 \mu \mathrm{L}$ of the samples ( 1 to $100 \mu \mathrm{g} \mathrm{mL}^{-1}$ ) were added to $300 \mu \mathrm{L}$ of distilled water and $3 \mathrm{~mL}$ of FRAP reagent, and the mixtures were incubated in a water bath at $37^{\circ} \mathrm{C}$ for $30 \mathrm{~min}$. The absorbance of the reaction mixture was read at $593 \mathrm{~nm}$ using a UV-Vis spectrophotometer (Lambda 35, Perkin Elmer Corporation, Massachusetts, USA), with FRAP solution as a blank. The calibration curve was constructed using different concentrations of $\mathrm{FeSO}_{4} \cdot 7 \mathrm{H}_{2} \mathrm{O}$ (100 to $2000 \mu \mathrm{M})\left(\mathrm{r}^{2}=0.9987\right)$ and the results are expressed as millimole of Fe" ${ }^{\mathrm{II}}$ per gram of sample. Standards of gallic acid and Trolox (Sigma) were treated under the same conditions as the samples.

\section{UV-Vis analysis of geopropolis extracts}

The UV-Vis spectra was obtained for each extract $(50 \mu \mathrm{L})$ in methanol $(3 \mathrm{~mL})$, and the absorption spectra was measured at the wavelength range of 200 to $450 \mathrm{~nm}$ using a UV-Vis spectrophotometer (Lambda 35, Perkin Elmer Corporation, Massachusetts, USA).

\section{Analysis of geopropolis extracts by gas chromatography-mass spectrometry (GC/MS)}

To assess geopropolis chemical composition, $1 \mathrm{mg}$ of dry HEGs was added of $300 \mu \mathrm{L}$ of pyridine and $100 \mu \mathrm{L}$ of bis-(trimethylsilyl) trifluoroacetamide (BSTFA) including $1 \%$ of trimethylchlorosilane (TMCS) in a sealed glass tube for $1 \mathrm{~h}$ at $80^{\circ} \mathrm{C}$ to prepare samples for gas chromatography according to Campos et al. (2014). The analyses were carried by gas chromatograph and mass spectrometry (GC/MS), using an Agilent GC (6890 Series gas chromatography system; Agilent Technologies, California, USA) quadrupole massselective detector (MSD) system (5973, Agilent Technologies, California, USA), and capillary column fused silica HP-5MS $(30 \mathrm{~m} \times 0.25 \mathrm{~mm}$ i.d., film thickness, $0.25 \mu \mathrm{m})$. The oven temperature was programmed to linearly increase from $70^{\circ} \mathrm{C}$ to $310{ }^{\circ} \mathrm{C}$ at $5^{\circ} \mathrm{C} \mathrm{min}{ }^{-1}$, with $1 \mathrm{~min}$ heating at $310^{\circ} \mathrm{C}$ and $60 \mathrm{~min}$ elution time. The system was balanced for $6 \mathrm{~min}$ at $70{ }^{\circ} \mathrm{C}$ before automatic injection of the subsequent sample. Injector temperature was $230^{\circ} \mathrm{C}$ and detector temperature was $250^{\circ} \mathrm{C}$; an ion source at $200{ }^{\circ} \mathrm{C}$, carrier Helium gas at $1.0 \mathrm{~mL} \mathrm{~min}^{-1}$, constant pressure mode, injection volume $1 \mu \mathrm{L}$; split ratio 10:1. Electron-impact mass spectra (EI-MS; $70 \mathrm{eV}$ ) were acquired over the mass-to-charge ratios $\left(\mathrm{m} \mathrm{z}^{-1}\right)$ range to 50 to 650 and a scan interval of $2 \mathrm{scan} \mathrm{s}^{-1}$. The identification of geopropolis compounds was based on the percentage of similarity plus comparison of mass spectra (MS) using software NIST AMIDS version 2.0 data library, with the percentage of total ion chromatograms (TIC\%). Gallic acid and ellagic acid, standards, were co-chromatographed and identified on the basis of the retention times (RT) and mass spectra (MS) fragmentation.

\section{Statistical analysis}

All analyses were performed in triplicate. The results are expressed as the mean \pm standard deviation (SD) and were analyzed using the GraphPad Prism 5.0 software. Comparisons between groups were made using analyses of variance (ANOVA) followed by Tukey's test $p$ value $\leq 0.05$ and Pearson's correlation.

\section{RESULTS}

Total phenolic content ranged from 126.6 to $847.5 \mathrm{mg}$ $\mathrm{GAE} \mathrm{g}^{-1}$ (Table 1), and antioxidant activity (expressed as $\mathrm{IC}_{50}$ in $\mu \mathrm{g} \mathrm{mL} \mathrm{L}^{-1}$ and as $\mathrm{mmol} \mathrm{Fe}^{\mathrm{II}} \mathrm{g}^{-1}$ ) of the hydroalcoholic extracts 
ranged from 4.24 to $44.44 \mu \mathrm{gLL}^{-1}$ and 1.29 to $18.42 \mathrm{mmol}$ $\mathrm{Fe}^{\mathrm{II}} \mathrm{g}^{-1}$ (Table 1).

In the DPPH assay, HEG4 $\left(\mathrm{IC}_{50}\right.$ value of $\left.4.24 \mu \mathrm{g} \mathrm{mL}^{-1}\right)$ and HEG3 $\left(5.92 \mu \mathrm{g} \mathrm{mL}^{-1}\right)$ had higher antioxidant activity than HEG1 and HEG2 ( IC $_{50}$ value of $19.05 \mu \mathrm{g} \mathrm{mL}^{-1}$ and $44.44 \mu \mathrm{g}$ $\mathrm{mL}^{-1}$, respectively). The FRAP assay showed that HEG3 and HEG4 exhibited the best ferric-reducing property (13.59 and $18.42 \mathrm{mmol} \mathrm{Fe}^{\mathrm{II}} \mathrm{g}^{-1}$, respectively), which was higher than that observed for Trolox. The correlations between the results of DPPH and FRAP assays and TPC are shown in Table 2.

A negative correlation was observed between DPPH and TPC (-0.878) and DPPH and FRAP $(-0.836)$, in which a low $\mathrm{IC}_{50}$ value in the DPPH assays was correlated with a high TPC and a high FRAP value and vice versa. The correlation between TPC and FRAP was positive (0.843), indicating a high reducing power.

The UV spectra of the geopropolis extracts were also evaluated. All four extracts had absorption peak at $\lambda_{\text {max }}$ at 268-275 nm, which was compatible with the presence of phenolic compounds.

Table 1. Total phenolic content (TPC) concentrations (mg GAE g-1) and antioxidant activity, 2,2-diphenyl-1-picrylhydrazyl, DPPH (IC50 in $\mu \mathrm{g} \mathrm{mL-1),}$ and ferric reducing antioxidant power, FRAP (in mmol Fell g-1), mean values ( \pm standard deviation; $n=3$ ) of the hydroalcoholic extract of geopropolis (HEG) in two phytogeographical regions, flooded fields and cerrado, in the municipalities of Palmeirândia and Fernando Falcão, Maranhão State, northeastern Brazil. HEG1 and HEG2 are geopropolis collected at Palmeirândia; HEG3 and HEG4 are geopropolis collected at Fernando Falcão.

\begin{tabular}{lccc}
\hline $\begin{array}{l}\text { Extracts } \\
(\mathrm{HEG})\end{array}$ & TPC $\left(\mathrm{mg} \mathrm{GAE} \mathrm{g}^{-1}\right)$ & $\begin{array}{c}\mathrm{DPPH} \mathrm{IC} \\
\left.\mathrm{mL}^{-1}\right)\end{array}$ & FRAP $\left(\mathrm{mmol} \mathrm{Fe} \mathrm{g}^{-1}\right)$ \\
\hline HEG1 & $212.30 \pm 0.290 \mathrm{a}$ & $19.05 \pm 0.012 \mathrm{a}$ & $1.78 \pm 0.007 \mathrm{a}$ \\
HEG2 & $126.60 \pm 0.840 \mathrm{~b}$ & $44.44 \pm 0.813 \mathrm{~b}$ & $1.29 \pm 0.016 \mathrm{a}, \mathrm{d}$ \\
\hline HEG3 & $847.50 \pm 0.040 \mathrm{c}$ & $5.92 \pm 0.120 \mathrm{c}$ & $13.59 \pm 0.430 \mathrm{~b}$ \\
HEG4 & $348.30 \pm 0.005 \mathrm{~d}$ & $4.24 \pm 0.015 \mathrm{c}$ & $18.42 \pm 0.210 \mathrm{c}$ \\
$\begin{array}{l}\text { Gallic } \\
\text { acid }\end{array}$ & - & $1.83 \pm 0.030 \mathrm{~d}$ & $0.73 \pm 0.040 \mathrm{~d}$ \\
\hline \begin{tabular}{l} 
Trolox \\
\hline
\end{tabular} & - & $5.11 \pm 0.040 \mathrm{c}$ & $9.09 \pm 0.100 \mathrm{e}$ \\
\hline
\end{tabular}

Different letters in the same column indicate a significant difference by Tukey test, $p$ $<0.05$.

Table 2. Pearson correlation coefficient between the 2,2-diphenyl-1picrylhydrazyl (DPPH) and ferric reducing antioxidant power (FRAP) assays and total phenolic content (TPC).

\begin{tabular}{lll}
\hline & DPPH & FRAP \\
\hline TPC & -0.878 & 0.843 \\
DPPH & & -0.836 \\
FRAP & -0.836 & \\
\hline
\end{tabular}

The chromatograms obtained by GC/MS permitted the identification of a large number of compounds in the four geopropolis extracts (Table 3). HEG1 and HEG2 had a similar composition. Triterpenoids were the main compounds, including cycloartane- (cycloartenol, 5.39\% and 4.12\%), oleanane- ( $\beta$-amyrin, $1.23 \%$ and $2.66 \%)$, and ursane-type triterpenoids (cycloursane, $1.62 \%$ and $0.83 \%$ and 3 -oxo-urs-

Table 3. Chemical composition of the hydroalcoholic extract of geopropolis (HEG) in two phytogeographical regions, flooded fields and cerrado, in the municipalities of Palmeirândia and Fernando Falcão, Maranhão State, northeastern Brazil, expressed in percentage of total ion chromatograms (TIC\%). HEG1 and HEG2 are geopropolis collected at Palmeirândia; HEG3 and HEG4 are geopropolis collected at Fernando Falcão). Each value denotes the mean of three analyses.

\begin{tabular}{|c|c|c|c|c|c|}
\hline \multirow[t]{2}{*}{$\begin{array}{l}\text { Compound } \\
\text { class }\end{array}$} & \multirow[t]{2}{*}{ Chemical constituents } & \multicolumn{4}{|c|}{ Extracts (HEG) TIC (\%) } \\
\hline & & HEG1 & HEG2 & HEG3 & HEG4 \\
\hline \multirow[t]{5}{*}{ Fatty acids } & Palmitic & 0.16 & 0.12 & 0.52 & 1.05 \\
\hline & Stearic & 0.46 & 0.39 & 1.53 & 3.44 \\
\hline & Linoleic & 0.15 & - & - & - \\
\hline & Melissic & - & 1.35 & - & - \\
\hline & Octenoic & - & 0.14 & - & - \\
\hline \multirow[t]{3}{*}{ Organic acids } & Glycolic & - & 0.01 & - & - \\
\hline & Gluconic & 0.07 & - & - & - \\
\hline & Quinic & - & - & 1.68 & 1.85 \\
\hline \multirow[t]{10}{*}{ Sugars } & Glucose & 0.08 & 0.02 & 24.3 & 14.93 \\
\hline & Fructose & - & - & 0.32 & 1.34 \\
\hline & Mannose & - & - & 12.80 & - \\
\hline & Arabinose & 0.15 & - & 0.13 & 1.24 \\
\hline & Galactose & 0.22 & 0.04 & - & - \\
\hline & Fucose & 0.13 & - & - & - \\
\hline & Sorbose & 0.05 & - & - & - \\
\hline & Xylose & 0.45 & - & 0.61 & - \\
\hline & Ribose & 0.12 & - & - & - \\
\hline & Aucubin & 0.17 & 0.07 & - & - \\
\hline \multirow[t]{6}{*}{ Alcohols } & Erythritol & 0.25 & 0.14 & - & 0.28 \\
\hline & Arabitol & 0.06 & - & - & - \\
\hline & Sorbitol & 0.11 & - & - & - \\
\hline & Glycerol & - & - & 0.22 & 0.27 \\
\hline & Xylitol & - & - & 0.92 & \\
\hline & Inositol & - & - & 0.10 & 0.45 \\
\hline \multirow[t]{3}{*}{ Phenolic acids } & Protocatechuic & 1.04 & 0.38 & 0.10 & 0.13 \\
\hline & Gallic & 0.66 & 1.03 & 22.30 & 18.90 \\
\hline & Ellagic & - & - & 14.70 & 13.60 \\
\hline \multirow[t]{5}{*}{ Triterpenes } & $\begin{array}{l}\text { Urs-12-en-24-oic } \\
\text { acid, 3-0xo }\end{array}$ & 0.99 & 0.61 & - & - \\
\hline & $\beta$-Amyrin & 1.23 & 2.66 & - & - \\
\hline & Unknown triterpene & 1.26 & 1.65 & - & - \\
\hline & Cycloursane & 1.62 & 0.83 & - & - \\
\hline & Cycloartenol & 5.39 & 4.12 & - & - \\
\hline \multirow[t]{2}{*}{ Steroids } & Lanosterol & 0.18 & 0.47 & - & - \\
\hline & Lanosterol acetate & 0.02 & - & - & - \\
\hline
\end{tabular}


12-en-24-oic acid, $0.99 \%$ and $0.61 \%$, respectively). The extracts also contained steroids, the phenols protocatechuic acid $(1.04 \%$ and $0.38 \%)$ and gallic acid $(0.66 \%$ and $1.03 \%)$, fatty acids, and sugars.

The chemical composition of HEG3 and HEG4 did not contain triterpenoids or steroids, but had a high concentration of phenolic compounds such as gallic acid (22.3\% and $18.9 \%$, respectively) and ellagic acid (14.7\% and $13.6 \%)$. These phenolic acids were identified and confirmed using an authentic standard based on massspectral fragmentation, total ion chromatograms (TIC\%), and retention times (RT). Sugars, especially glucose $(24.3 \%$ and $14.93 \%)$ and mannose $(12.8 \%)$ were identified.

\section{DISCUSSION}

In the state of Maranhão, meliponiculture is predominant activity in flooded fields and cerrado areas, especially in the municipalities of Palmeirândia and Fernando Falcão where the geopropolis samples were collected.

HEG3 and HEG4 contain higher levels of polyphenols than HEG1 and HEG2; thus, the determination of total phenol content has become a standard test and is usually evaluated by Folin-Ciocalteu method (Sawaya et al. 2011). Our findings are in line with the results of studies conducted by Cunha et al. (2009) on geopropolis extracts from Palmeirândia, Maranhao State, by Dutra et al. (2014) on geopropolis from Fernando Falcão, Maranhao State, and by Silva et al. (2013) on geopropolis produced by the Amazonian species $M$. interrupta and M. seminigra.

Two different methods, the DPPH scavenging and FRAP metal ions, were used to determine the antioxidant properties of geopropolis, which allowed us to obtain information about the activity of these extracts during different stages of the oxidation reactions (Souza et al. 2013).

According to Campos et al. (2003), extracts and natural substances are considered active at $\mathrm{IC}_{50}<500 \mu \mathrm{g} \mathrm{mL} \mathrm{L}^{-1}$. In the DPPH and FRAP assays, all extracts exhibited significant in vitro antioxidant activity. The correlations between the results of the DPPH and FRAP assays and TPC suggest that total phenols were responsible for the antioxidant activity and are consistent with results of studies investigating geopropolis produced by $M$. interrupta, $M$. seminigra, $M$. fasciculata, and M. subnitida (Silva et al. 2013; Souza et al. 2013; Dutra et al. 2014; Souza et al. 2014). A high phenolic content is related to antioxidant activity and all extracts exhibited high levels of polyphenols (Table 1), as confirmed by GC/MS (Table 3).

Chromatographic methods are essential for the analysis of products that contain complex mixtures, permitting the identification and quantification of biologically active compounds (Sawaya et al. 2011; Righi et al. 2013).
Geopropolis is a complex mixture of chemical substances. Thus, all extracts were subjected to GC/MS for complete analysis. MS provides information of molecular mass and structural information, and thereby the identification of the components of a mixture.

The triterpenic compounds found in our study corroborate the findings by Araújo et al. (2015) who analyzed the chemical composition of geopropolis collected in Palmeirândia. Triterpenes have been identified in propolis and geopropolis produced by stingless bees in Brazil and Mexico (Bankova and Popova 2007).

Protocatechuic acid has been detected in propolis produced by the stingless bee Tetragonisca angustula (Pereira et al. 2003) and in propolis (Kalogeropoulos et al. 2009) and pollen (Bonvehí et al. 2001) produced by Apis mellifera. However, there are no reports on the presence of this compound in geopropolis produced by $M$. fasciculata.

The chemical composition of HEG3 and HEG4 is similar, but differs from that of HEG1 and HEG2, as the former do not contain triterpenoids and steroids but exhibit high concentrations of phenolic compounds. Gallic acid and its derivatives have been identified in geopropolis and propolis of stingless bees in the Brazilian states of Maranhão (Dutra et al. 2014), Pernambuco, Paraná, São Paulo (Velikova et al. 2000), Piauí (Bankova et al. 1998) and Tocantins (Araújo et al. 2016).

HEG3 and HEG4 exhibited the highest in vitro antioxidant activities of the four extracts, suggesting a positive relationship between high levels of ellagic and gallic acids and antioxidant activity. Phenolic acids (gallic acid, ellagic acid, and protocatechuic acid) have been reported to be strong antioxidants (Kakkar and Bais 2014; Zhang et al. 2014).

The botanical sources used by stingless bees for the production of geopropolis can influence its chemical composition. Analysis of the geopropolis collected in Fernando Falcáo suggests that the botanical sources are rich in phenolic compounds, particularly phenolic acids and hydrolyzable tannins found in HEG3 and HEG4, as it was also observed by Dutra et al. (2014).

It is noteworthy the presence of phenolic acids, triterpenoids, and steroids in geopropolis because it may predict the pharmacological properties of this natural product such as antimicrobial (Libério et al. 2011), antioxidant (Dutra et al. 2014), anticancer and immunomodulatory activities (Araújo et al. 2015).

\section{CONCLUSIONS}

The geopropolis collected in Palmeirândia contained triterpene compounds of the cycloartane, ursane, and oleanane type as the main compounds, in addition to phenolic acids, protocatechuic and gallic acid. In contrast, 
geopropolis collected in Fernando Falcão contained high concentrations of phenolic acids (gallic acid and ellagic acid) and exhibited high antioxidant activity, suggesting that the high levels of phenolic acids are responsible for the antioxidant property of this geopropolis. The chemical composition and antioxidant activity contribute to the identity and quality of the types of geopropolis produced by $M$. fasciculata collected in two phytogeographical regions of the Maranhão State, northeastern Brazil.

\section{ACKNOWLEDGEMENTS}

The authors wish to thank the Coordination for the Improvement of Higher Education Personnel (Project No 925/2010), the National Council for Scientific and Technological Development (Project No. 554318/2010-5) and the Foundation for the Support of Research Scientific and Technological Development of the State of Maranháo (Project No. 00963/09) for financial support. Thanks to the beekeepers for donating the geopropolis samples.

\section{REFERENCES}

Araújo, M.J.A.M.; Búfalo, M.C.; Conti, B.J.; Fernandes Junior, A.; Trusheva, B.; Bankova, V.; Sforcin, J.M. 2015. The chemical composition and pharmacological activities of geopropolis produced by Melipona fasciculata Smith in Northeast Brazil. Journal of Molecular Pathophysiology, 4: 12-20.

Araújo, K.S.S.; Santos Júnior, J.F.; Sato, M.O.; Finco, F.D.B.A.; Soares, I.M.; Barbosa R.S.; Alvim, T.C.; Ascêncio, S.D.; Mariano, S.M.B. 2016. Physicochemical properties and antioxidant capacity of propolis of stingless bees (Meliponinae) and Apis from two regions of Tocantins, Brazil. Acta Amazonica, 46: 61-68.

Bankova, V.; Christov, R.; Marcucci, M.C.; Popov, S. 1998. Constituents of Brazilian geopropolis. Zeitschrift für Naturforschung C, 53: 402-406.

Bankova, V. 2009. Chemical diversity of propolis makes it a valuable source of new biologically active compounds. Journal of ApiProduct and ApiMedical Science, 1: 23-28.

Bankova, V.; Popova, M. 2007. Propolis of stingless bees: a promising source of biologically active compounds. Pharmacognosy Reviews, 1: 88-92.

Barth, O. M.; Freitas, A.S. 2015. Palynology as a tool to distinguish between propolis and geopropolis: southern Brazilian samples. Open Access Library Journal, 2: e2217.

Bezerra, J.M.D. 2002. Meliponicultura: Uma atividade essencial para a economia familiar do Trópico Úmido. In: Moura, E.G. (Org). Agroambientes de transição entre o trópico úmido e o semi-árido: Atributos, alteraçóes e uso na produção familiar. Universidade Estadual do Maranhão, São Luís, Maranhão, p.144-203. (http://www.iica.org.br/docs/publicacoes/publicacoesiica/ agroabientestransicao.pdf)_Accessed on 20/09/2015.

Bonvehí, J.S.; Torrentó, M.S.; Lorente, E.C. 2001. Evaluation of polyphenolic and flavonoid compounds in honeybee collected pollen in Spain. Journal of Agricultural and Food Chemistry, 49: 1848-1853.

Campos, M.G.; Webby, R.F.; Markham, K. R.; Mitchell, K.A.; Cunha, A.P. 2003. Age-induced diminution of free radical scavenging capacity in bee pollens and the contribution of constituent flavonoids. Journal of Agricultural and Food Chemistry, 51: 742-745.

Campos, J.F.; Santos, U.P.; Macorini, L.F.B.; Melo, A.M.M.F.; Balestieri, B.P.J.; Paredes-Gamero, E.J.; Cardoso, C.A.L.; Souza, K.P.; Santos, E.L. 2014. Antimicrobial, antioxidant and cytotoxic activities of propolis from Melipona orbignyi (Hymenoptera, Apidae). Food and Chemical Toxicology, 65: 374-380.

Cunha, M.S.; Dutra, R.P.; Batista, M.C.A.; Abreu, B.V.B.; Santos, J.R.; Neiva, V.A.; Amaral, F.M.M.; Ribeiro, M.N.S. 2009. Padronização de extrativos de geoprópolis de Melipona fasciculata Smith (tiúba). Cadernos de Pesquisa, 16: 31-38.

Dutra, R.P.; Nogueira, A.M.C.; Marques, R.R.O.; Costa, M.C.P.; Ribeiro, M.N.S. 2008. Pharmacognostic evaluation of geopropolis of Melipona fasciculata Smith from Baixada Maranhense, Brazil. Revista Brasileira de Farmacognosia, 18: 557-562.

Dutra, R.P.; Abreu, B.V.B.; Cunha, M.S.; Batista, M.C.A.; Torres, L.M.B.; Nascimento, F.R.F.; Ribeiro, M.N.S.; Guerra, R.N.M. 2014. Phenolic acids, hydrolyzable tannins, and antioxidant activity of geopropolis from the stingless bee Melipona fasciculata Smith. Journal of Agricultural and Food Chemistry, 62: 2549-2557.

Holanda, C.A.; Oliveira, A.R.; Costa, M.C.P.; Ribeiro, M.N.S.; Souza, J.L.; Araújo, M.J.A.M. 2012. Qualidade dos méis produzidos por Melipona fasciculata Smith da região do Cerrado maranhense. Quimica Nova, 35: 55-58.

Kakkar, S.; Bais, S. 2014. A review on protocatechuic acid and its pharmacological potential. International Scholarly Research Notices Pharmacology, 2014: ID 952943.

Kalogeropoulos, N.; Konteles, S.J.; Troullidou, E.; Mourtzinos, I.; Karathanos, V.T. 2009. Chemical composition, antioxidant activity and antimicrobial properties of propolis extracts from Greece and Cyprus. Journal of Agricultural and Food Chemistry, 116: 452-461.

Kerr, W.E. 1987. Abelhas indígenas brasileiras (meliponíneos) na polinização e na produção de mel, pólen, geoprópolis e cera. Informe Agropecuário, 13: 15-27.

Libério, S.A.; Pereira, A.L.A.; Dutra, R. P.; Reis, A.S.; Araújo, M.J.A.M.; Mattar, N.S.; et al. 2011. Antimicrobial activity against oral pathogens and immunomodulatory effects and toxicity of geopropolis produced by the stingless bee Melipona fasciculata Smith. BioMed Central Complementary and Alternative Medicine, 11: 108.

Martins, A.C.L.; Rêgo, M.M.C.; Carreira, L.M.M.; Albuquerque, P.M.C. 2011. Espectro polínico de mel de tiúba (Melipona fasciculata Smith, 1854, Hymenoptera, Apidae). Acta Amazonica, 41: 183-190.

Muniz, F.H. 2002. A vegetação da região de transição entre a Amazônia e o Nordeste, diversidade e estrutura. In: Moura, 
E.G. (Org). Agroambientes de Transição entre o Trópico Úmido e o Semi-árido: Atributos, alteraçóes e uso na produçáo familiar. Universidade Estadual do Maranhão, São Luís, Maranhão, p.44-60.

Nogueira-Neto, P. 1997. Vida e criaçâo de abelhas indígenas sem ferrão. Nogueirapis, São Paulo, São Paulo, 446p.

Pedro, S.R.M. 2014. The stingless bee fauna in Brazil (Hymenoptera: Apidae). Sociobiology, 61: 348-354.

Pereira, A.S.; Bicalho, B.; Aquino-Neto, F.R. 2003. Comparison of propolis from Apis mellifera and Tetragonisca angustula. Apidologie, 34: 291-298.

Ribeiro, M.H.M.; Luz, C.F.P.; Albuquerque, P.M.C. 2013. Pollen analysis of geopropolis of Melipona (Melikerria) fasciculata Smith, 1854 (Meliponini, Apidae, Hymenoptera) in areas of restinga, cerrado and flooded fields in the state of Maranháo, Brazil. Grana, 52: 81-92.

Righi, A. A.; Negri, G.; Salatino, A. 2013. Comparative chemistry of propolis from eight Brazilian localities. Evidence-Based Complementary and Alternative Medicine, 2013: ID 267878.

Sawaya, A.C.H.F.; Cunha, I.B.S.; Marcucci, M.C. 2011. Analytical methods applied to diverse types of Brazilian propolis. Chemistry Central Journal, 5: 27.

Silva, E.C.C.; Muniz, M.P.; Nunomura, R.C.S.; Nunomura, S.M.; Zilse, G.A.C. 2013. Constituintes fenólicos e atividade antioxidante da geoprópolis de duas espécies de abelhas sem ferrão amazônicas. Quimica Nova, 36: 628-633.
Slaa, E.J.; Chaves, L.A.S.; Malagodi-Braga, K.S.; Hofstede, F.E. 2006. Stingless bees in applied pollination: practice and perspectives. Apidologie, 37: 293-315.

Souza, S.A.; Camara, C.A.; Silva, E.M.S.; Silva, T.M.S. 2013. Composition and antioxidant activity of geopropolis collected by Melipona subnitida (Jandaíra) bees. Evidence-Based Complementary and Alternative Medicine, 2013: ID 801383.

Souza, S.A.; Dias, T.L.M.F.; Silva, T.M.G.; Falcão, R.A.; Moreira, M.S.A.; Silva, E.M.S.; Camara, C.A.; Silva, T.M.S. 2014. Chemical composition, antinociceptive and free radicalscavenging activities of geopropolis from Melipona subnitida Ducke (Hymenoptera: Apidae: Meliponini). Sociobiology, 61: 560-565.

Velikova, M.; Bankova, V.; Marcucci, M.C.; Tsvetkova, I.; Kujumgiev, A. 2000. Chemical composition and biological activity of propolis from Brazilian meliponinae. Zeitschrift für Naturforschung C, 55: 785-789.

Zhang, L.L.; Wang, Y.M.; Xu, M.; Wu, D.M.; Chen, J.H. 2014. Quantification of gallic acid and ellagic acid from the seed of Cornus officinalis by UHPLC method and their antioxidant activity. Chemical Engineering Communications, 201: 545-556.

Recebido em 08/01/2016

Aceito em 25/03/2016 
